\title{
The economy of the North-East region of Brazil based on the 2011 regional input-output matrix
}

\author{
Marcos Falcão Gonçalves, Mateus de Carvalho Reis Neves \\ and Marcelo José Braga
}

\begin{abstract}
This paper seeks to determine the leading sectors of the economy of the North-East region of Brazil based on input-output matrix methodology and the economic structure of 2011. For that purpose, the regional input-output matrix was updated from 2004 to 2011 and, subsequently, the Rasmussen-Hirschman linkage indices, field of influence and pure linkage indices were calculated, along with the type I and II multipliers of production, employment and income. The results confirm the importance of the textile and chemical sectors, along with those related to the oil industry, and show that the production of intermediate goods is one of the characteristics of the North-East region's economy.
\end{abstract}

\section{Keywords}

Economic conditions, economic development, regional development, industrial production, employment, income, input-output analysis, Brazil

JEL classification

R10, R11, R13

Authors

Marcos Falcão Gonçalves is General Coordinator of Studies and Research, Evaluation, Technology and Innovation of the Superintendency for the Development of the North-East (SUDENE), Brazil. Email: marcos.falcao@sudene.gov.br.

Mateus de Carvalho Reis Neves is a professor in the Department of Rural Economics (DER) of the Federal University of Viçosa (UFV), Minas Gerais, Brazil. Email: mateus.neves@ufv.br.

Marcelo José Braga is a professor in the Department of Rural Economics (DER) of the Federal University of Viçosa (UFV), Minas Gerais, Brazil. Email: mjbraga@ufv.br. 


\section{Introduction}

In the 1970s, efforts to decentralize the Brazilian economy through public investment in infrastructure (roads, ports, energy, etc.) and in strategic industrial sectors picked up pace, including under the Second National Development Plan (1975-1979) (Government of Brazil, 1970). ${ }^{1}$ As a result of these initiatives, large production complexes were established in the North-East² from 1970-1984 (Galindo, 1997).

The decentralization process appears to be ongoing, as the South-East region's share in the value of industrial transformation fell from $69.3 \%$ in 1996 to $61.6 \%$ in 2004, while that of the North-East region increased from $4.3 \%$ to $10.1 \%$ (BCB, 2006). This underscores the economic growth of the North-East in spite of the heterogeneous characteristics of this process, in which some dynamic areas of regional development coexist with entire areas that are stagnant and lacking in production modernization.

The input-output matrix has often been employed in the design or analysis of public policies. Its widespread use is justified by its capacity to predict the potential effects of a shock in the final demand of a certain sector, both on the sector itself and on the rest of the economy.

Thus, it allows policymakers to stimulate sectors considered key -i.e., those in which a final demand shock spreads most strongly to the rest of the economy, both upstream (backward) and downstream (forward) in the production chain - and to identify and clear production bottlenecks.

Against this backdrop, as noted by Tosta, Lirio and Silveira (2004), input-output models have contributed to a wide range of economic works and analyses, as they facilitate the evaluation of the impact of production changes in a specific sector on different sectors.

However, works on the economy of the North-East based on this methodology remain scarce. In one of these studies, Guilhoto and others (2012) present a more theoretical and methodological approach and build a regional input-output table (base year 2004), calculating the main indicators and also presenting data by State. Drawing on the work of Guilhoto and others (2012), Ribeiro and others (2013) analysed Suape (an industrial port complex located in the State of Pernambuco) and the potential economic effects of the construction of the Abreu e Lima refinery, which they considered the core of the industry driving development.

The input-output matrix was also used by Morrone (2017) to examine the basic economic structure of Rio Grande do Sul in 2008 and to estimate the impact of the increase in the tax on the circulation of goods and services (ICMS) on final demand and economic activity in the State. The study showed the negative effect of the measure, which limited the possibilities for regional development.

Montoya, Finamore and Pasqual (2012) also used the input-output matrix to analyse the sources of growth and structural change in the economy of Rio Grande do Sul from 1998-2003. The matrix reflects the reduction and resumption of economic growth.

Similarly, Ribeiro and Leite (2012) conducted an analysis focused on States and built an input-output matrix for the State of Sergipe, using the RAS method for the construction of regional matrices. ${ }^{3}$ According to the authors, the Sergipe economy faced problems relating to the supply of inputs in sectors crucial to the State's development because, in addition to sectoral concentration and limited international integration, there were few key sectors to stimulate local growth.

\footnotetext{
1 See Lessa (1977), Delgado (1985) and Fishlow (1986) for more details on the Second National Development Plan (1975-1979) and the Brazilian economic context of that period.

2 Notably, the petrochemical complex in Camaçari, Bahia; the integrated petrochemical complex in Sergipe; the chlorochemical and rock salt complex in Alagoas; the sugar and alcohol complex on the eastern coast of Pernambuco and Alagoas; agroindustry within the irrigated perimeter of the São Francisco River where it runs through Pernambuco and Bahia; the port industry of Suape, in Pernambuco; the chemical and metallurgical industry of Rio Grande do Norte; the textile and garment industry in Ceará; the mineral and metallurgical industry in Maranhão; and oil production along the North-East coast (Galindo, 1997).

3 See Miller (1998, p. 89) for more details on the RAS method.
} 
Considering regional vicissitudes, the aim of this work is to determine the sectors that currently play a leading role in the economy of the North-East region of Brazil based on input-output matrix methodology and the economic structure of 2011, and to raise important points to guide public policies targeting the region's development. For that purpose, the regional input-output matrix was updated from 2004 to 2011 and, subsequently, the Rasmussen-Hirschman linkage indices, ${ }^{4}$ field of influence ${ }^{5}$ and pure linkage indices ${ }^{6}$ were calculated, along with the type I and II multipliers of production, employment and income. ${ }^{7}$

In order to better understand the instruments used, the second section presents a brief theoretical foundation for the input-output model. The third section examines the methodology used in this work, while section four identifies the main economic sectors of the North-East region, and is followed by final considerations.

\section{Theoretical foundation}

According to Miller and Blair (2009), an input-output model consists of a system of linear equations, each of which describes the distribution of a sector's products throughout the economy. Its basic objective is to analyse the interdependence of economic sectors. Guilhoto and others (2012) compare the input-output model proposed by Leontief (1966) with an "economic snapshot" of the economy itself, which can show how sectors are linked or, in other words, identify the sectors that demand products and services and those that supply them.

Input-output tables are often used to represent this interdependence, which is systematized in table 1.

Table 1

Leontief input-output matrix for two sectors

\begin{tabular}{|c|c|c|c|c|c|c|c|c|c|c|}
\hline \multirow{3}{*}{\multicolumn{2}{|c|}{ Sectors }} & \multicolumn{8}{|c|}{ Purchases (j) } & \multirow{3}{*}{$\begin{array}{c}\text { Gross } \\
\text { production } \\
\text { value }\end{array}$} \\
\hline & & \multicolumn{3}{|c|}{ Intermediate demand } & \multicolumn{5}{|c|}{ Final demand } & \\
\hline & & Sector 1 & Sector 2 & Subtotal & $\mathrm{C}$ & 1 & $\mathrm{G}$ & $E$ & Subtotal & \\
\hline \multirow{2}{*}{ Sales (i) } & Sector 1 & $Z_{11}$ & $Z_{12}$ & $\sum_{j=1}^{2} z_{i j}$ & $C_{1}$ & $I_{1}$ & $G_{1}$ & $E_{1}$ & $Y_{1}$ & $X_{1}$ \\
\hline & Sector 2 & $Z_{21}$ & $Z_{22}$ & & $C_{2}$ & $I_{2}$ & $G_{2}$ & $E_{2}$ & $Y_{2}$ & $X_{2}$ \\
\hline \multicolumn{2}{|l|}{ Subtotal } & $\sum_{i=1}^{2} z_{i 1}$ & $\sum_{i=1}^{2} z_{i 2}$ & $\sum_{i, j=1}^{2} z_{i j}$ & $\sum_{i=1}^{2} C_{i}$ & $\sum_{i=1}^{2} I_{i}$ & $\sum_{i=1}^{2} G_{i}$ & $\sum_{i=1}^{2} E_{i}$ & $\sum_{i=1}^{2} Y_{i}$ & $\sum_{i=1}^{2} X_{i}$ \\
\hline \multicolumn{2}{|l|}{ Imports } & $M_{1}$ & $M_{2}$ & $\sum_{i=1}^{2} M_{j}$ & & & & & & \\
\hline \multicolumn{2}{|l|}{ Net indirect taxes } & $T_{1}$ & $T_{2}$ & $\sum_{i=1}^{2} T_{j}$ & & & & & & \\
\hline \multicolumn{2}{|l|}{ Value added } & $V A_{1}$ & $V A_{2}$ & $\sum_{i=1}^{2} V A_{j}$ & & & & & & \\
\hline \multicolumn{2}{|c|}{ Gross production value } & $X_{1}$ & $X_{2}$ & $\sum_{i=1}^{2} X_{j}$ & & & & & & \\
\hline
\end{tabular}

Source: Prepared by the authors on the basis of J. J. M. Guilhoto, Análise de insumo-produto: teoria, fundamentos e aplicações, São Paulo, School of Economics, Management and Accounting, University of São Paulo (FEA/USP), 2007.

\footnotetext{
4 See Rasmussen (1956) and Hirschman (1958).

5 See Mendes, Pereira and Teixeira (2011).

6 See Guilhoto and others (1994).

7 See Miller and Blair (2009).
} 
Where $z_{i j}$ is the supply of inputs from sector $i$ to sector $j ; C_{i}$ is the supply of sector $i$ earmarked for private final consumption; $I_{i}$ is the supply of sector $i$ allocated to private investment; $G_{i}$ is the supply of sector $i$ set aside for the government (consumption and investment); $E_{i}$ is the supply of sector $i$ earmarked for exports to the rest of the world; $Y_{i}$ represents the total final demand met by sector $i\left(C_{i}+I_{i}+G_{i}+E_{i}\right)$; $X_{i}$ represents the gross production value of sector $i$ (or total supply of $i$ ); $M_{j}$ represents the imports of sector $j$; $T_{j}$ represents the total net indirect taxes collected by sector $j$; $V A_{j}$ is the total gross value added of sector $j$; and $C_{j}$ is the total production cost of sector $j$.

Table 1 is used to obtain the production equation through equation (1):

$$
X_{i}=\sum_{j=1}^{2} z_{i j}+Y_{i}
$$

Considering the assumptions of the Leontief model contained in Miller and Blair (2009), namely: (i) fixed relationships between a sector's inputs and its output and (ii) constant returns to scale, and the technical coefficient of production, also called the input-output coefficient or direct input coefficient, we obtain through equation (2):

$$
a_{i j}=\frac{z_{i j}}{x_{j}}
$$

where $a_{i j}$ is the technical coefficient that indicates the quantity of inputs of sector $i$ necessary for the production of one unit of final output in sector $j$.

Applying (2) to (1) and generalizing to $n$ sectors, we obtain equation (3):

$$
X_{i}=\sum_{j=1}^{n} a_{i j} x_{j}+Y_{i}
$$

In matrix form, equation (3) can be written as (4):

$$
X=A X+Y
$$

Since final demand is exogenous, it follows that:

$$
X-A X=Y
$$

or, too:

$$
(I-A)^{-1} Y=X
$$

where the term $(I-A)^{-1}$, also called matrix $B$, corresponds to the matrix of direct and indirect coefficients, or the Leontief matrix. The dimension of this matrix is $n \times n$, where $n$ indicates the number of sectors considered, whose elements can be represented by $b_{i j}$.

On the basis of the national model, Miller and Blair (2009) proposed a regional model, as shown in table 2. 
Table 2

Intersectoral and interregional flow of goods

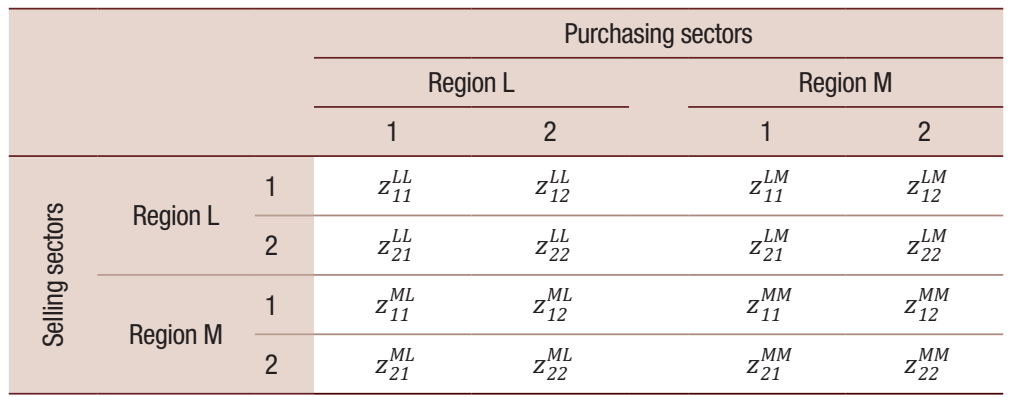

Source: Prepared by the authors on the basis of E. R. Miller and P. D. Blair, Input-Output Analysis: Foundations and Extensions, Cambridge, Cambridge University Press, 2009.

Bear in mind the hypothetical intersectoral and interregional flow of goods to regions $L$ and $M$, both with two sectors, in which $z_{i j}^{L L}$ is the monetary flow from sector $i$ to sector $j$ in region $L ; z_{i j}^{M M}$ is the monetary flow from sector $i$ to sector $j$ in region $\mathrm{M} ; z_{i j}^{L M}$ is the monetary flow from sector $i$ in region $\mathrm{L}$ to sector $j$ in region $\mathrm{M}$; and $z_{i j}^{M L}$ is the monetary flow from sector $i$ in region $\mathrm{M}$ to sector $j$ in region $\mathrm{L}$.

\section{Methodology}

The methodology used in this article is based on the input-output matrix, with productive linkages between activities and the determination of key economic sectors, specifically evaluated through Rasmussen-Hirschman indices, fields of influence and pure linkage indices, in addition to production, employment and income multipliers, which are described below.

\section{Rasmussen-Hirschman linkage index}

The linkage index developed by Rasmussen (1956) and Hirschman (1958) makes it possible to determine the economic sectors which reflect the strongest linkages and which, therefore, can be considered key sectors. ${ }^{8}$

Estimation starts with matrix $B$, i.e., the Leontief inverse matrix, described in equation (5.B). According to Guilhoto and others (2012), the Rasmussen-Hirschman linkage index can be found using equations (6) and (7):

$$
\begin{aligned}
& U_{j}=B_{* j} / n / B^{*} \\
& U_{i}=B_{i^{*}} / n / B^{*}
\end{aligned}
$$

where $U_{j}$ is the backward linkage index and $U_{i}$ corresponds to the forward linkage index; $B$ is the Leontief inverse matrix; $B^{*}$ is the average of all the elements of $B ; B_{*_{j}}$ and $B_{i^{*}}$, correspond, respectively, to the sum of each column and each row of $B$; and $n$ is the number of economic sectors. The backward linkage index indicates the extent to which one sector demands inputs from the other sectors, while the forward linkage index indicates the extent to which the outputs of one sector are demanded by other sectors.

8 See Hewings and others (1989) for a discussion of key economic sectors. 
According to Haddad (1989), index values above unity may denote key sectors, which are strongly linked with upstream and downstream sectors in the production chain. However, Guilhoto and others (2012) note that the application of the Rasmussen-Hirschman linkage index methodology makes it difficult to determine the coefficients that, when modified, produce a greater impact on the system as a whole. The analysis of the field of influence was developed to fill this gap.

\section{Field of influence}

According to Mendes, Pereira and Teixeira (2011), the field of influence approach describes the way in which changes in direct coefficients are distributed throughout the economic system as a whole and makes it possible to determine the relationships between the most important sectors in the production process. Thus, the field of influence shows the extent to which each sector links backward and forward to all the other economic sectors.

To arrive at that result, we use a matrix of direct coefficients $A=\left|\alpha_{i j}\right|$, defining the matrix of incremental variations in direct coefficients of input $E=\left|\varepsilon_{i j}\right|$. The corresponding Leontief matrices are given by equation (8):

$$
B=[I-A]^{-1}=\left|b_{i j}\right|
$$

and by equation (9):

$$
B(\varepsilon)=[I-A-\varepsilon]^{-1}=\left|b_{i j}(\varepsilon)\right|
$$

If the variation is small and only occurs in a direct coefficient, we obtain:

$$
\varepsilon_{i j}= \begin{cases}\varepsilon, & i=i_{1}, j=j_{1} \\ 0, & i \neq i_{1}, j \neq j_{1}\end{cases}
$$

The field of influence of this variation can be approximated using the expression (11):

$$
F\left(\varepsilon_{i j}\right)=\frac{\left[B\left(\varepsilon_{i j}\right)-B\right]}{\varepsilon_{i j}}
$$

where $F\left(\varepsilon_{i j}\right)$ is a matrix $(n \times n)$ of the field of influence of coefficient $\alpha_{i j}$.

To determine the coefficients with the greatest field of influence, it is necessary to associate a value with each matrix $F\left(\varepsilon_{i j}\right)$. Thus,

$$
S_{i j}=\sum_{k=1}^{n} \sum_{l=1}^{n}\left[f_{k l}\left(\varepsilon_{i j}\right)\right]^{2}
$$

where $S_{i j}$ is the value associated with matrix $F\left(\varepsilon_{i j}\right)$. Therefore, the direct coefficients with the highest values of $S_{i j}$ will be those with the greatest field of influence within the economy as a whole. 


\section{Pure linkage indices}

According to Mendes, Pereira and Teixeira (2011), pure linkage indices - which complement the analysis of the input-output matrix - determine the behaviour of the production structure, considering the level of production of each sector and allowing the measurement of interactions between sectors in terms of production value. Also known as the GHS index, ${ }^{9}$ it was proposed by Guilhoto and others (1994) with the objective of isolating the effects of each sector on the economic system as a whole.

Therefore, considering the matrix of direct input coefficients, $A$ (based on 5.B), which represents an input-output system for a given sector $j$, and the rest of the economy, we obtain:

$$
A=\left[\begin{array}{ll}
A_{j j} & A_{j r} \\
A_{r j} & A_{r r}
\end{array}\right]
$$

where $A_{j j}$ and $A_{r r}$ are square matrices of direct inputs of sector $j$ and the rest of the economy, respectively; and $A_{j r}$ and $A_{r j}$ are rectangular matrices showing, respectively, the direct inputs purchased by sector $j$ from the rest of the economy and the direct inputs purchased by the rest of the economy from sector $j$. Based on the following Leontief inverse matrix:

$$
B=(I-A)^{-1}=\left[\begin{array}{ll}
B_{j j} & B_{j r} \\
B_{r j} & B_{r r}
\end{array}\right]=\left[\begin{array}{cc}
\Delta_{j j} & 0 \\
0 & \Delta_{r r}
\end{array}\right]\left[\begin{array}{cc}
\Delta_{j} & 0 \\
0 & \Delta_{r}
\end{array}\right]\left[\begin{array}{cc}
I & A_{j r} \Delta_{r} \\
A_{r j} \Delta_{j} & I
\end{array}\right]
$$

the elements are defined as:

$$
\begin{gathered}
\Delta_{j}=\left(I-A_{j j}\right)^{-1} \\
\Delta_{r}=\left(I-A_{r r}\right)^{-1} \\
\Delta_{j j}=\left(I-\Delta_{j} A_{j r} \Delta_{r} A_{r j}\right)^{-1} \\
\Delta_{r r}=\left(I-\Delta r A r j \Delta_{j} A_{j r}\right)^{-1}
\end{gathered}
$$

Thus, from (14), it is possible to determine the production process within the economy and derive a set of multipliers or linkages represented by the matrices. By combining (15) and (5.B), it is possible to derive a set of indices that can be used both to rank sectors according to their importance in the production value generated, and to determine the production process within the economy.

From (14) and (5.B), it follows that:

$$
\left[\begin{array}{l}
X_{j} \\
X_{r}
\end{array}\right]=\left[\begin{array}{cc}
\Delta_{j j} & 0 \\
0 & \Delta_{r r}
\end{array}\right]\left[\begin{array}{cc}
\Delta_{j} & 0 \\
0 & \Delta_{r}
\end{array}\right]\left[\begin{array}{cc}
I & A_{j r} \Delta_{r} \\
A_{r j} \Delta_{j} & I
\end{array}\right]\left[\begin{array}{c}
Y_{j} \\
Y_{r}
\end{array}\right]
$$

from which it is possible to derive the definitions of the pure backward linkage index $(P B L)$ and the pure forward linkage index (PFL), given respectively by (20) and (21):

9 In honour of its creators, Guilhoto, Hewings and Sonis. 


$$
\begin{aligned}
& P B L=\Delta_{r} A_{r j} \Delta_{j} Y_{j} \\
& P F L=\Delta_{j} A_{j r} \Delta_{r} Y_{r}
\end{aligned}
$$

The $P B L$ provides the pure impact of the value of total output of sector $j$ on the rest of the economy, while the PFL provides the pure impact of the value of total output of the rest of the economy on sector $j$. As both are in current values, we can proceed as in equation (22):

$$
P T L=P B L+P F L
$$

The values of the indices are normalised by the average value of the economic sectors, which allows a comparison, over time, in economies experiencing inflation or changes in the monetary standard. According to Nunes and others (2012), a sector is considered key -from the perspective of normalized pure linkage indices - when the values of the normalized pure total linkage indices (PTL) exceed unity $(P T L>1)$.

\section{Multipliers}

As noted by Tosta, Lirio and Silveira (2012), production, employment and income multipliers are often used to quantify the effects of exogenous changes on selected economic activities and can be classified into type I and type II multipliers. The fundamental difference between these two types is that the second model considers households' consumption, as well as their respective remuneration, endogenously.

Basically, Miller and Blair (2009) define employment and income multipliers as the increase in employment or wages, respectively, given a shock to final demand, which can be represented mathematically by the expression (23):

$$
m(h)_{j}=\sum_{i=1}^{n} \alpha_{n+1} \cdot b_{i j}
$$

where $m(h)_{j}$ is the employment (or income) multiplier for sector $j ; \alpha_{n+1}$ is the ratio of the number of persons employed in the sector (or value added to the economy) to the sector's output; and $b_{i j}$ is the element in row $i$ and column $j$ of the Leontief inverse matrix.

As defined by Miller and Blair (2009), the output multiplier for a specific sector is the total value of production in all economic sectors required to satisfy one additional monetary unit of final demand for the output of that sector. Mathematically, it can be expressed as:

$$
m(o)_{j}=\sum_{i=1}^{n} b_{i j}
$$

where $m(o)_{j}$ is the output multiplier for sector $j$; and $b_{i j}$ is the element in row $i$ and column $j$ of the Leontief inverse matrix.

Type II multipliers can be found algebraically by means of the equations presented in (23) and (24). However, the Leontief inverse matrix is based on a matrix of technical coefficients in which households are endogenous to the model. Schematically, considering an economy with only two sectors, the matrix $A$ is given by: 


$$
A=\left[\begin{array}{ccc}
X_{11} / X_{1} & X_{12} / X_{2} & C_{1} / U \\
X_{21} / X_{1} & X_{22} / X_{2} & C_{2} / U \\
V A_{1} / X_{1} & V A_{2} / X_{2} & 0
\end{array}\right]
$$

where $X_{i j}$ is the output of sector $i$ to serve sector $j ; X_{j}$ is the total output of sector $j$; $C_{i}$ is the private consumption of sector $i$; $U$ is the sum of private consumption; and $V A_{j}$ is the total gross value added of sector $j$.

As type II multipliers consider households endogenously, they tend to minimize the problem of underestimation posed by type I multipliers.

\section{Updating of the input-output matrix}

The starting point for building the input-output matrix for the North-East region and the rest of Brazil in 2011 was similar to that proposed by Guilhoto and others (2012) for 2004. This matrix includes 12 areas, namely: the States within the jurisdiction of the Superintendency for the Development of the North-East (SUDENE) (Alagoas, Bahia, Ceará, Maranhão, Paraíba, Pernambuco, Piauí, Rio Grande do Norte, Sergipe, and parts of Espírito Santo and Minas Gerais) and the rest of Brazil. First, the matrix of technical coefficients (Matrix $A$ ) was determined for 2004, by dividing intermediate consumption by the respective gross production value. This was used to obtain the Leontief inverse matrix (Matrix $\left.B=(I-A)^{-1}\right)$, of dimension 1,332 x 1,332.

The system of national accounts of the Brazilian Institute of Geography and Statistics (IBGE, 2014) was used to measure the variation of regional value added for the North-East States from 2004-2011. The ratio between the volume of gross value added in 2004 and that of 2011 was considered, taking into account the 111 sectors and activities listed in table 3.

Table 3

Brazil: selected activities and sectors of the input-output matrix of the North-East region, 2011

\begin{tabular}{llll}
\hline \multicolumn{2}{l}{ Sector or activity } & \multicolumn{2}{l}{ Sector or activity } \\
\hline 1 & Maize & 57 & Metallurgy of non-ferrous metals \\
\hline 2 & Sugar cane & 58 & Metal products, except machinery and equipment \\
\hline 3 & Soybean & 59 & Agricultural machinery and tools \\
\hline 5 & Fruit growing & 60 & Machinery and equipment for oil exploration and extraction \\
\hline 6 & Other crops & 61 & Other machinery and equipment \\
\hline 7 & Vegetable production & 62 & Household appliances \\
\hline 8 & Cattle & 63 & Office machinery and computer equipment \\
\hline 9 & Other animals & 64 & Electrical machinery, equipment and materials \\
\hline 10 & Pigs & 65 & Electronic and communications equipment \\
\hline 11 & Poultry & 66 & Medical and hospital measuring and optical \\
\hline 12 & Fish & 67 & Cars, vans and utility vehicles \\
\hline 13 & Oil and other & 68 & Trucks and buses \\
\hline 14 & Natural gas & 69 & Motor vehicle parts and accessories \\
\hline 15 & Services related to oil and gas extraction & 70 & Other transport equipment \\
\hline 16 & Iron ore & 71 & Furniture industry \\
\hline 17 & Other products of the extractive industry & 72 & Miscellaneous industries \\
\hline 18 & Slaughter of cattle & 73 & Electricity production \\
\hline 19 & Slaughter of pigs and other animals & 74 & Electricity distribution \\
\hline 20 & Slaughter of poultry & 75 & Piped gas \\
\hline 21 & Vegetable oil production & 76 & Water and sewerage \\
\hline & & 77 & Urban cleaning services \\
\hline
\end{tabular}


Table 3 (concluded)

\begin{tabular}{|c|c|c|c|}
\hline \multicolumn{2}{|c|}{ Sector or activity } & \multicolumn{2}{|c|}{ Sector or activity } \\
\hline 22 & Dairy industry & 78 & Construction \\
\hline 23 & Processing of other vegetable products & 79 & Wholesale trade \\
\hline 24 & Poultry feed & 80 & Fuel retail trade \\
\hline 25 & Sugar production & 81 & Vehicles, parts and accessories retail trade \\
\hline 26 & Coffee industry & 82 & Supermarkets \\
\hline 27 & Other food products & 83 & Other retail trade \\
\hline 28 & Beverages & 84 & Cargo transport by road \\
\hline 29 & Tobacco products & 85 & Cargo transport by air \\
\hline 30 & Textiles & 86 & Cargo transport by rail \\
\hline 31 & Clothing and accessories & 87 & Cargo transport by water \\
\hline 32 & Leather goods and footwear & 88 & Cargo transport by pipeline \\
\hline 33 & Wood products, except furniture & 89 & Ancillary cargo transport activities \\
\hline 34 & Production of cellulose and mechanical pulp & 90 & Passenger transport by road \\
\hline 35 & Production of paper, cardboard and paper products & 91 & Passenger transport by air \\
\hline 36 & Newspapers, magazines, records & 92 & Passenger transport by rail \\
\hline 37 & Oil and coke refining & 93 & Passenger transport by water \\
\hline 38 & Alcohol & 94 & Ancillary passenger transport activities \\
\hline 39 & Other chemical elements & 95 & Postal services \\
\hline 40 & Fertilizers & 96 & Mobile telephone services \\
\hline 41 & Manufacturing of basic petrochemical products & 97 & Fixed-line telephone services \\
\hline 42 & Manufacturing of intermediate products for resins and fibres & 98 & Other information services \\
\hline 43 & Manufacturing of other organic chemical products & 99 & Financial intermediation and insurance \\
\hline 44 & Manufacturing of resins and elastomers & 100 & Real estate and rental services \\
\hline 45 & $\begin{array}{l}\text { Manufacturing of artificial and synthetic } \\
\text { fibres, wires and cables }\end{array}$ & 101 & Maintenance and repair services \\
\hline 46 & Pharmacy and veterinary services & 102 & Accommodation services \\
\hline 47 & Pesticides & 103 & Food services \\
\hline 48 & Perfume, hygiene and cleaning products & 104 & Business services \\
\hline 49 & Paints, varnishes, enamels and lacquers & 105 & Private education \\
\hline 50 & Miscellaneous chemical products and preparations & 106 & Private health care \\
\hline 51 & Rubber industry & 107 & Other services \\
\hline 52 & Plastic items & 108 & Public education \\
\hline 53 & Cement & 109 & Public health care \\
\hline 54 & Manufacturing of glass and glass products & 110 & Public security \\
\hline 55 & Other non-metallic mineral products & 111 & Other public administration and social security services \\
\hline 56 & Manufacturing of steel and steel products & & \\
\hline
\end{tabular}

Source: Prepared by the authors on the basis of official information.

The final demand items for 2011 were estimated by calculating the product of 2004 final demand and the respective value added growth ratios. The sum of these items generated a column vector $(1,332 \times 1)$, which represented final demand for 2011. Multiplying the Leontief inverse matrix (matrix $B$ ) by that vector gives the gross production value for 2011 , which is also a column vector $(1,332 \times 1)$.

The intermediate consumption matrix for 2011 (dimension 1,332x1,332) was obtained by taking the matrix of technical coefficients (matrix $A$ ) and multiplying it by the gross production value. Next, the column vector of gross production value was transposed, giving rise to the row vector of dimension $1 \times 1,332$ from which the sum of each column of intermediate consumption was subtracted, which determined the value added to production for 2011. The same proportion recorded in 2004 was used to update the values relating to taxes and to disaggregate the value added items.

To determine the item "employed personnel", the annual variation of employed personnel was measured for each sector or activity from 2003-2008 (most recent year for which data were available), and used to estimate figures for the year 2011. 
After updating the input-output matrix, the 12 areas were aggregated into only 2 areas, the first one including the 9 States of the North-East region and the second one integrating Minas Gerais and Espírito Santo into the rest of Brazil. ${ }^{10}$

\section{Results and analysis}

\section{Rasmussen-Hirschman linkage indices}

Table 4 shows eight sectors with strong linkages, both upstream (backward) and downstream (forward) in the production chain, namely: oil and other (13), textiles (30), oil and coke refining (37), fertilizers (40), manufacturing of basic petrochemical products (41), manufacturing of resins and elastomers (44), manufacturing of steel and steel products (56), and metal products (except machinery and equipment) (58). With the exception of the second sector, all the sectors and activities listed belong to the intermediate goods industry, which means they reflect strong linkages. Thus, according to Prado (1981) and Guilhoto and others (1994), these sectors and activities can be considered key to the North-East region's economy in 2011 and strategic to the formulation of sectoral policies.

Table 4

North-East region of Brazil: Rasmussen-Hirschman linkage indices for 111 selected sectors, 2011

\begin{tabular}{|c|c|c|c|c|c|c|c|c|c|c|c|}
\hline Sector & Forward & Backward & Sector & Forward & Backward & Sector & Forward & Backward & Sector & Forward & Backward \\
\hline 1 & 0.72354 & 0.82314 & 29 & 0.53872 & 1.13799 & 57 & 0.76379 & 1.05482 & 85 & 0.66087 & 1.13846 \\
\hline 2 & 1.01153 & 0.70596 & 30 & 1.08843 & 1.08328 & 58 & 1.01705 & 1.03178 & 86 & 0.61709 & 0.97824 \\
\hline 3 & 0.77160 & 0.70299 & 31 & 0.55268 & 1.04472 & 59 & 0.55290 & 1.13785 & 87 & 0.76187 & 0.99129 \\
\hline 4 & 0.67836 & 0.71155 & 32 & 0.61421 & 1.21382 & 60 & 0.54061 & 1.11377 & 88 & 0.70264 & 1.10395 \\
\hline 5 & 1.21008 & 0.77743 & 33 & 0.71347 & 1.03333 & 61 & 0.63537 & 1.11008 & 89 & 1.02975 & 0.91238 \\
\hline 6 & 0.70688 & 0.83189 & 34 & 0.58320 & 1.11122 & 62 & 0.53675 & 1.13188 & 90 & 0.65240 & 0.90732 \\
\hline 7 & 0.63879 & 0.69577 & 35 & 0.81300 & 1.05756 & 63 & 0.55504 & 1.13211 & 91 & 0.63151 & 1.10386 \\
\hline 8 & 1.05394 & 0.85847 & 36 & 0.68633 & 0.96709 & 64 & 0.79273 & 1.08242 & 92 & 0.53382 & 0.89684 \\
\hline 9 & 0.57570 & 0.88255 & 37 & 2.34460 & 1.23225 & 65 & 0.66517 & 1.20464 & 93 & 0.52896 & 0.87796 \\
\hline 10 & 0.74281 & 1.00538 & 38 & 0.60660 & 0.94458 & 66 & 0.56500 & 0.90767 & 94 & 0.62746 & 0.78737 \\
\hline 11 & 0.97111 & 0.91979 & 39 & 0.96093 & 1.16268 & 67 & 0.55683 & 1.32781 & 95 & 0.70868 & 0.78479 \\
\hline 12 & 0.53958 & 0.93099 & 40 & 1.23459 & 1.18894 & 68 & 0.53936 & 1.30662 & 96 & 0.97496 & 0.87398 \\
\hline 13 & 1.02749 & 1.01047 & 41 & 1.10412 & 1.14821 & 69 & 0.88599 & 1.18658 & 97 & 1.05959 & 0.87310 \\
\hline 14 & 0.90663 & 1.01397 & 42 & 0.98196 & 1.28876 & 70 & 0.67221 & 1.19708 & 98 & 1.10018 & 0.82491 \\
\hline 15 & 0.57316 & 0.77573 & 43 & 0.82138 & 1.21740 & 71 & 0.55676 & 1.03816 & 99 & 2.27300 & 0.83964 \\
\hline 16 & 0.53174 & 0.93498 & 44 & 1.41930 & 1.22334 & 72 & 0.57476 & 1.05912 & 100 & 1.02986 & 0.56296 \\
\hline 17 & 0.83825 & 0.95853 & 45 & 0.59717 & 1.11244 & 73 & 1.13878 & 0.64641 & 101 & 0.82337 & 0.71133 \\
\hline 18 & 0.61142 & 1.21165 & 46 & 0.56599 & 0.97388 & 74 & 1.61589 & 0.84980 & 102 & 0.54363 & 0.85866 \\
\hline 19 & 0.56294 & 1.28510 & 47 & 0.87593 & 1.18945 & 75 & 0.91970 & 1.05248 & 103 & 0.68086 & 0.98353 \\
\hline 20 & 0.56295 & 1.23139 & 48 & 0.62772 & 1.08760 & 76 & 0.66747 & 0.69770 & 104 & 2.63910 & 0.77858 \\
\hline 21 & 0.67299 & 1.30239 & 49 & 0.60998 & 1.21366 & 77 & 0.60692 & 0.82046 & 105 & 0.58584 & 0.83967 \\
\hline 22 & 0.58696 & 1.28826 & 50 & 0.68712 & 1.17829 & 78 & 0.77135 & 0.90079 & 106 & 0.57086 & 0.91791 \\
\hline 23 & 0.54419 & 1.17096 & 51 & 0.63465 & 1.12974 & 79 & 3.15717 & 0.69120 & 107 & 0.78992 & 0.80256 \\
\hline 24 & 0.66304 & 1.23598 & 52 & 0.61817 & 1.20879 & 80 & 0.69760 & 0.67856 & 108 & 0.53063 & 0.67256 \\
\hline 25 & 0.70647 & 1.02986 & 53 & 0.62865 & 0.94440 & 81 & 0.66004 & 0.73072 & 109 & 0.52677 & 0.82817 \\
\hline 26 & 0.59904 & 1.29563 & 54 & 0.56697 & 1.00374 & 82 & 0.55883 & 0.71953 & 110 & 0.53168 & 0.82946 \\
\hline 27 & 0.77187 & 1.27484 & 55 & 0.65966 & 1.04157 & 83 & 0.57337 & 0.69741 & 111 & 0.68703 & 0.78170 \\
\hline 28 & 0.72714 & 1.11985 & 56 & 1.03698 & 1.07267 & 84 & 1.86853 & 0.93173 & & & \\
\hline
\end{tabular}

Source:Prepared by the authors on the basis of official information.

Notes: The sectors are listed in table 3. The highlighted sectors reflect a backward or forward Rasmussen-Hirschman index greater than unity.

\footnotetext{
10 Microsoft $\circledast$ Excel $₫ 2013$ and MATLAB® R2010a software were used to estimate the matrices, coefficients and multipliers.
} 
Despite the importance of the petrochemical industry in the value of industrial transformation in the North-East region (highlighted by the linkage indices), Wanderley (2008) states that its growth did not translate into proportional development in some industries that would naturally benefit from the strong forward linkages in the chemical industry. In some industries - such as pharmaceuticals, perfumery and plastics, among others - there was no significant increase. This performance indicates that the raw materials of the chemical industry were not used in the North-East, probably owing to the lack of an incentive programme for the development of the sectors that use these raw materials, which would favour the linkages of the chemical industry in the region. The results of the observation of the field of influence, presented below, reflect this.

\section{Field of influence}

As a complement to the examination of the Rasmussen-Hirschman linkage indices, the analysis of the field of influence shows the notable performance of key sectors with respect to the other sectors analysed, as shown in annex table A1.1.

The observation of the field of influence of the North-East region's economy in 2011 validates the condition confirmed by the Rasmussen-Hirschman backward and forward linkage indices.

Thus, the evaluation of the field of influence reveals that the oil and other sector (13) demands products and services from sectors such as other transport equipment (70) and cargo transport by pipeline (88), indicating the importance of transport providers for the oil industry.

There are many linkages relating to the textile sector (30), characterised by the demand for inputs from sectors linked to agricultural activities (20,21, 22, 25 and 26) and the purchase of their output, among others, by the wholesale trade sector (79). According to Garcia (2010), the configuration of local production systems is a fairly common feature of the textile, clothing and footwear industries in the North-East region. Given the simplicity of the technical base of these sectors and the ample opportunities for product segmentation, there is a strong incentive for the emergence and existence of a vast array of small specialized businesses. Moreover, the geographic concentration of businesses allows producers to enjoy the benefits deriving from business agglomerates and the interactions between them.

Another important sector, oil and coke refining (37), demands inputs and services from sectors such as cargo transport by pipeline (88) and financial intermediation and insurance (99), while it has backward linkages with sectors such as textiles (30), electronic and communications equipment (65) and fertilizers (40).

The manufacturing of resins and elastomers (44) has backward linkages with sectors such as oil and coke refining (37), cargo transport by pipeline (88) and financial intermediation and insurance (99), and provides outputs to the following sectors: textiles (30), electronic and communications equipment (65) and wood products, except furniture (33).

The aforementioned linkages reinforce the importance of the sectors considered key according to the Rasmussen-Hirschman linkage index. They also indicate basically the same dominant industries upstream and downstream in the production chain of the North-East region's economy, and underscore the importance of financial services, transport and logistics and the manufacturing of electronic and communications equipment. 


\section{Pure linkage indices}

When evaluating the economy of the North-East region from the perspective of normalized pure linkage indices, or GHS indices, five sectors and activities reflect a total coefficient (PTL) greater than unity, namely: oil and coke refining (37); construction (78); financial intermediation and insurance (99); business services (104) and other public administration and social security services (111) (see table 5).

Table 5

North-East region of Brazil: normalized forward (PFL), backward (PBL) and total (PTL) GHS indices for 111 selected sectors, 2011

\begin{tabular}{|c|c|c|c|c|c|c|c|c|c|c|c|}
\hline Sector & PFL & PBL & PTL & Sector & PFL & PBL & PTL & Sector & PFL & $P B L$ & PTL \\
\hline 1 & 0.1216 & 0.0710 & 0.0963 & 38 & 0.0886 & 0.0880 & 0.0883 & 75 & 0.2025 & 0.2763 & 0.2395 \\
\hline 2 & 0.3527 & 0.0282 & 0.1901 & 39 & 0.3190 & 0.0597 & 0.1891 & 76 & 0.1784 & 0.1254 & 0.1518 \\
\hline 3 & 0.2023 & 0.0609 & 0.1315 & 40 & 0.4681 & 0.1198 & 0.2936 & 77 & 0.0920 & 0.0561 & 0.0740 \\
\hline 4 & 0.1224 & 0.0932 & 0.1078 & 41 & 0.4975 & 0.1015 & 0.2991 & 78 & 0.5148 & 3.2660 & 1.8932 \\
\hline 5 & 0.4748 & 0.1844 & 0.3293 & 42 & 0.3734 & 0.1500 & 0.2615 & 79 & 1.3992 & 0.3721 & 0.8846 \\
\hline 6 & 0.0857 & 0.0371 & 0.0613 & 43 & 0.2231 & 0.1011 & 0.1619 & 80 & 0.3940 & 0.0887 & 0.2411 \\
\hline 7 & 0.0526 & 0.0120 & 0.0322 & 44 & 0.7285 & 0.3449 & 0.5363 & 81 & 0.1266 & 0.2286 & 0.1777 \\
\hline 8 & 0.3478 & 0.1511 & 0.2493 & 45 & 0.0241 & 0.0195 & 0.0218 & 82 & 0.0172 & 0.3828 & 0.2004 \\
\hline 9 & 0.0171 & 0.0034 & 0.0102 & 46 & 0.0288 & 0.0344 & 0.0316 & 83 & 0.0281 & 0.4883 & 0.2587 \\
\hline 10 & 0.0663 & 0.0470 & 0.0566 & 47 & 0.2327 & 0.0539 & 0.1431 & 84 & 0.7078 & 0.0406 & 0.3735 \\
\hline 11 & 0.1845 & 0.1249 & 0.1546 & 48 & 0.0866 & 0.1250 & 0.1058 & 85 & 0.0382 & 0.0383 & 0.0383 \\
\hline 12 & 0.0152 & 0.0265 & 0.0209 & 49 & 0.1123 & 0.0240 & 0.0680 & 86 & 0.0288 & -0.0155 & 0.0066 \\
\hline 13 & 0.6904 & 0.0417 & 0.3654 & 50 & 0.0800 & 0.0330 & 0.0564 & 87 & 0.1173 & 0.2710 & 0.1943 \\
\hline 14 & 0.3607 & -0.0750 & 0.1424 & 51 & 0.0514 & 0.0163 & 0.0338 & 88 & 0.0275 & 0.0079 & 0.0177 \\
\hline 15 & 0.0384 & 0.0026 & 0.0204 & 52 & 0.0262 & 0.0031 & 0.0146 & 89 & 0.2630 & 0.0321 & 0.1473 \\
\hline 16 & 0.0007 & 0.0010 & 0.0009 & 53 & 0.2433 & -0.0009 & 0.1210 & 90 & 0.1304 & 0.8949 & 0.5134 \\
\hline 17 & 0.2787 & 0.0596 & 0.1689 & 54 & 0.0400 & 0.0072 & 0.0236 & 91 & 0.1132 & 0.0202 & 0.0666 \\
\hline 18 & 0.0982 & 0.3946 & 0.2467 & 55 & 0.3140 & 0.0346 & 0.1740 & 92 & 0.0064 & 0.0206 & 0.0135 \\
\hline 19 & 0.0112 & 0.0403 & 0.0258 & 56 & 0.2843 & 0.2005 & 0.2423 & 93 & 0.0022 & 0.0012 & 0.0017 \\
\hline 20 & 0.0099 & 0.0817 & 0.0459 & 57 & 0.1678 & 0.2089 & 0.1884 & 94 & 0.0640 & 0.0238 & 0.0438 \\
\hline 21 & 0.1066 & 0.3323 & 0.2197 & 58 & 0.2985 & 0.1618 & 0.2301 & 95 & 0.1362 & 0.0081 & 0.0720 \\
\hline 22 & 0.0233 & 0.0747 & 0.0490 & 59 & 0.0047 & 0.0129 & 0.0088 & 96 & 0.4568 & 0.0641 & 0.2601 \\
\hline 23 & 0.0141 & 0.0503 & 0.0322 & 60 & 0.0008 & 0.0010 & 0.0009 & 97 & 0.4932 & 0.1960 & 0.3443 \\
\hline 24 & 0.1411 & 0.2858 & 0.2136 & 61 & 0.0380 & 0.0960 & 0.0671 & 98 & 0.5755 & -0.0036 & 0.2854 \\
\hline 25 & 0.0958 & 0.2941 & 0.1951 & 62 & 0.0022 & 0.0306 & 0.0164 & 99 & 1.7043 & 0.3481 & 1.0248 \\
\hline 26 & 0.0323 & 0.0856 & 0.0590 & 63 & 0.0140 & 0.1125 & 0.0633 & 100 & 0.4912 & 0.1938 & 0.3422 \\
\hline 27 & 0.2345 & 0.6963 & 0.4659 & 64 & 0.1186 & 0.0644 & 0.0914 & 101 & 0.1964 & 0.0613 & 0.1287 \\
\hline 28 & 0.2815 & 0.4787 & 0.3803 & 65 & 0.0101 & 0.0241 & 0.0171 & 102 & 0.0303 & 0.1361 & 0.0833 \\
\hline 29 & 0.0001 & 0.0243 & 0.0122 & 66 & 0.0071 & 0.0204 & 0.0137 & 103 & 0.2442 & 0.9961 & 0.6209 \\
\hline 30 & 0.4939 & 0.3259 & 0.4097 & 67 & 0.0039 & 0.8466 & 0.4261 & 104 & 2.1540 & 0.0491 & 1.0995 \\
\hline 31 & 0.0372 & 0.3856 & 0.2117 & 68 & 0.0014 & 0.0362 & 0.0188 & 105 & 0.0747 & 0.4932 & 0.2844 \\
\hline 32 & 0.0251 & 0.6542 & 0.3403 & 69 & 0.0931 & 0.0268 & 0.0598 & 106 & 0.0393 & 1.0400 & 0.5406 \\
\hline 33 & 0.0458 & 0.0104 & 0.0281 & 70 & 0.0035 & 0.0316 & 0.0176 & 107 & 0.2527 & 1.0419 & 0.6481 \\
\hline 34 & 0.0454 & 0.1020 & 0.0738 & 71 & 0.0254 & 0.1832 & 0.1044 & 108 & 0.0039 & 0.7653 & 0.3854 \\
\hline 35 & 0.1041 & 0.0337 & 0.0688 & 72 & 0.0546 & 0.0479 & 0.0513 & 109 & 0.0001 & 1.2929 & 0.6478 \\
\hline 36 & 0.1430 & 0.0507 & 0.0968 & 73 & 0.6315 & -0.0273 & 0.3014 & 110 & 0.0052 & 0.3788 & 0.1923 \\
\hline 37 & 1.3422 & 0.7978 & 1.0694 & 74 & 0.7904 & 0.5608 & 0.6754 & 111 & 0.1209 & 3.9736 & 2.0512 \\
\hline
\end{tabular}

Source: Prepared by the authors on the basis of official information.

Notes: The sectors are listed in table 3. The highlighted sectors reflect a GHS index greater than unity.

Among the key sectors determined according to the Rasmussen-Hirschman criterion, only oil and coke refining (37) is also noteworthy according to the GHS methodology. In addition, the financial intermediation and insurance sector, which already stood out as an important service provider, now emerges as a key sector when examining the field of influence. This indicates that these sectors were important to the North-East economy in 2011. 
Some sectors not highlighted by the Rasmussen-Hirschman methodology appear as key sectors according to the methodology of pure linkage indices, for example other public administration and social security services (111), as also shown by Mendes and others (2011) when analysing the economy of Minas Gerais.

\section{Multipliers}

The results obtained with the multiplier method, shown below, demonstrate the effects on employment, wages and production of a change in final demand in each selected sector or activity. Since the effects are propagated along the entire chain, backwards and forwards with respect to the target sector, industries with stronger linkages tend to present the highest multipliers. See annex tables A1.1 and A2.1, which contain type I and II multipliers, respectively.

With respect to type I multipliers, oil and coke refining reflects the highest employment multiplier (98.19) and the second highest wage multiplier (10.84), indicating the dynamism of this sector. Thus, for every increase of 1 million reais in final demand in this sector, there is an expectation of an increase or maintenance of 98.19 direct and indirect jobs and there is a tendency for wages in the economy to respond positively by 10.84 times in relation to the value of the initial shock. This result is consistent with that obtained by Nunes, Capucho and Parré (2012) when analysing the Brazilian economy, taking 2008 as the base year. Other sectors, linked to the energy industry as well, also generated significant results in terms of employment growth, as in the case of the piped gas sector (80.04) and the oil and other sector (38.79).

When considering the output multiplier, each increase of 1 million reais in final demand in the cars, vans and utility vehicles sector should result in an increase of 2.52 times that value in the total economic output, similar to that found by Guilhoto and others (2012) when analysing the economy of the North-East region in 2004. Other sectors, such as vegetable oil production (2.47), the coffee industry (2.46), the dairy industry (2.45) and the slaughter of pigs and other animals (2.44), are all part of agribusinesses which, in general, respond well to sectoral demand stimuli in terms of increased production.

In the case of type II multipliers, which differ from type I multipliers by making the "household spending" sector endogenous, changes are observed in the magnitude of the multiplier values, as well as in the ranking of the selected sectors or activities, which may lead to suggestions for formulating more targeted and effective public policies.

According to the results obtained with the type II multiplier, the oil and coke refining sector continues to present the highest employment multiplier (118.60) and is the third largest wage multiplier (12.06). In other words, for every increase of 1 million reais in the final demand of this sector, there is an expectation of an increase or maintenance of 118.60 direct, indirect and induced jobs and a tendency for wages in the economy to increase 12.06 times in relation to the value of the initial shock.

In the oil and other sector, there is an increase of 48.09 jobs, and the value of production in relation to the shock doubles. Another sector linked to the oil industry, natural gas, also responds significantly to the increase in demand, generating 35.84 additional direct, indirect and induced jobs and more than tripling the value of the shock in relation to wages.

Bearing in mind that the non-metallic mineral extraction and refining sites and chemical complexes are generally located in limited areas of the North-East region, these results appear to reflect, according to Lima and Simões (2010), the strengthening of heterogeneity within the region itself, where stagnant areas of selective and limited modernization (when it exists), coexist with dynamic areas where the production structure is quite modern and contributes significantly to the performance of the region as a whole. ${ }^{11}$

\footnotetext{
${ }^{11}$ As a mitigating counterpoint to this situation, it can be deduced that a significant movement of "employment insourcing" is under way in the North-East region. According to BCB data (2006), while 45.9\% of the industry's jobs were carried out in the region in 1996, this figure had already risen to $51.6 \%$ in 2004.
} 
In general, sectors with significant inputs downstream in the production chain are rising as a result of the changes in the economy of the North-East region since the implementation of the Second National Development Plan (1975-1979). According to Lima and Simões (2010), this reflects a trend towards greater complementarity between the industrial segments of the North-East and the rest of the country, especially the South-East region, despite the relocation of industries producing durable consumer goods to the North-East, especially to Bahia. In addition, the search for extra-regional consumer markets has reaffirmed the position of the North-East as a supplier of inputs for the other regions of the country, reflecting its special role in the interregional division of industrial labour in Brazil.

\section{Final considerations}

The analysis of the results obtained from the application of different methodologies to examine the inputoutput matrix has shown the importance of traditional sectors in the economy of the North-East region. Worthy of note are the textile industry and the sectors promoted within the framework of the Second National Development Plan (1975-1979), such as the chemical, resin and elastomer, and oil sectors.

It has also underscored the importance, albeit incipient, of sectors such as electronic and communications equipment, and pointed out that most of these sectors rely heavily on logistics systems and financial services.

Given the linkages in several sectors, it was confirmed that the economy of the North-East is still based, in part, on the organization established by the development policies of the 1970s and 1980s. The region remains a hub supplying intermediate goods to industries in other regions of the country, despite the recent relocation of some durable consumer goods industries to some States in the North-East. Consequently, the region's development is not an autonomous process and depends on the rest of the country.

However, for the integration of production to be effective, it must be based on planning that includes physical transport and logistics infrastructure that interconnects the different regions, as well as national projects that include energy generation and distribution, data transmission capacity and, above all, quality education.

Thus, the action of State and municipal governments is very important to close still wide gaps between regions, through tax incentives and structural improvements that also allow the decentralization of production and direct it to the North-East region, which is sometimes forgotten and lacks more thriving production sectors.

Those responsible for formulating public policy should pay more attention to incentives for the rural sector, given that activities relating to the growing of sugar cane and other crops and raising livestock reflect strong forward linkages.

Agro-industrial activities also reflect strong backward linkages that enhance value added, helping to support the inhabitants of rural areas and to improve their well-being thanks to the combination of the multiplier effects of employment and wages.

The textile sector, which in the past played a dominant role in the economy of some States in the North-East region, also represents a potential source of regional dynamism, given its strong influence upstream and downstream in the production chain. This justifies the need for stimulation through targeted public policies. 


\section{Bibliography}

BCB (Central Bank of Brazil) (2006), "Desconcentração regional da produção da indústria de transformação", Relatório de Inflação [online] https://www.bcb.gov.br/content/ri/relatorioinflacao/200609/RELINF200609ri200609b1p.pdf.

Delgado, G. C. (1985), Capital financeiro e agricultura no Brasil, 1965-1985, Ícone Editora.

Fishlow, A. (1986), "A economia política do ajustamento brasileiro aos choques do petróleo: uma nota sobre o período 1974/84", Pesquisa e Planejamento Econômico, vol. 16, No. 3.

Galindo, O. (org.) (1997), "Necessidades de infraestrutura econômica do Nordeste. Banco do Nordeste do Brasil. Diretrizes para um Plano de Ação do BNB (1991-1995)", Infraestrutura Econômica e Social do Nordeste, vol. 7, Fortaleza.

Garcia, R. (2010), "Uma análise dos processos recentes de desconcentração regional nas indústrias têxtil e de calçados e a importância dos sistemas locais de produção", Revista Econômica do Nordeste (REN), vol. 41, No. 1.

Government of Brazil (1970), II Plano Nacional de Desenvolvimento (1975-1979), Brasilia.

Guilhoto, J. J. M. (2007), Análise de insumo-produto: teoria, fundamentos e aplicações, São Paulo, School of Economics, Management and Accounting, University of São Paulo (FEA/USP).

Guilhoto, J. J. and others (2012), Matriz de insumo-produto do nordeste e estado: metodologia e resultados, Brasilia, Institute of Applied Economic Research (IPEA).

Guilhoto, J. J. M and others (1994), "Índices de ligação e setores-chave da economia Brasileira: 1959/80", Pesquisa e Planejamento Econômico, vol. 24, No. 2.

Haddad, P. R. and others (org.) (1989), Economia Regional: teorias e métodos de análise, Brasilia, Instituto de Investigación Económica Aplicada (IPEA).

Hewings, G. J. and others (1989), "Key sectors and structural change in the Brazilian economy: a comparison of alternative approaches and their policy implications", Journal of Policy Modeling, vol. 11, No. 1.

Hirschman, A. O. (1958), The Strategy of Economic Development, New Haven, Yale University Press.

IBGE (Brazilian Geographical and Statistical Institute) (2014), "Sistema de Contas Nacionais" [online] http:// www.ibge.gov.br.

Leontief, W. W. (1966), The Structure of American Economy: 1919-1939, New York, Oxford University.

Lessa, C. (1977), "Visão crítica do II PND", Revista Tibiriçá, vol. 2, No. 6.

Lima, A. C. da C. and R. F. Simões (2010), "Centralidade e emprego na região Nordeste do Brasil no período 1995/2007", Nova Economia, vol. 20, No. 1.

Mendes, C. S., M. W. G. Pereira and E. C. Teixeira (2011), "Uma análise do insumo-produto do setor lácteo mineiro”, Revista Econômica do Nordeste (REN), Fortaleza-CE, vol. 42, No. 03, July/September.

Miller, R. (1998), "Regional and interregional input-output analysis", Methods of Interregional and Regional Analysis, I. Aziz and others, Aldershot, Ashgate.

Miller, R. and P. D. Blair (2009), Input-Output Analysis: Foundations and Extensions, Cambridge, Cambridge University Press.

Montoya, M. A., E. B. Finamore and C. A. Pasqual (2012), "Fontes de crescimento e mudança estrutural na economia gaúcha: uma análise do Valor Bruto da Produção (VBP) e do emprego", Ensaios FEE, vol. 33, No. 2, November.

Morrone, H. (2017), "Estimando os impactos do aumento do ICMS na economia gaúcha: uma análise de insumo-produto", Revista Economia Ensaios, vol. 31, No. 2, Uberlândia, Minas Gerais, January/June.

Nunes, P. A., T. O. Capucho and J. L. Parré, (2012), "Estrutura produtiva Brasileira e Paranaense: comparações sobre os índices de ligação (R-H e GHS) e os multiplicadores de produção, renda e emprego", Revista de Desenvolvimento Econômico (RDE), Salvador, year XIV, No. 25, June.

Prado, E. F. S. (1981), Estrutura Tecnológica de Desenvolvimento Regional, São Paulo, University of São Paulo.

Rasmussen, P. (1956), Studies in Intersectoral Relations, Amsterdam, North-Holland.

Ribeiro, L. C. S. and A. P. V. Leite (2012), "Estrutura econômica do Estado de Sergipe em 2006: uma contribuição através da matriz de insumo-produto", Revista Econômica do Nordeste (REN), vol. 43, No. 04, Fortaleza, October-December.

Ribeiro, L. C. S. and others (2013), "Suape: um novo polo de crescimento?", Novos Cadernos NAEA, vol. 16, No. 1, June.

Tosta, M. C. R., V. S. Lirio and S. F. R. Silveira (2004), "Matrizes de insumo-produto: construção, uso e aplicações", Métodos Quantitativos em Economia, M. L. dos Santos and W. C. Vieira (eds.), Viçosa, Federal University of Viçosa.

Wanderley, L. A. (2008), "Integração nacional e fragmentação regional da indústria de transformação: Sudeste e Nordeste", Revista Economia Política do Desenvolvimento, vol. 1, No. 3. 


\section{Annex A1}

\section{Type I production, employment and income multipliers in the North-East region, 2011}

Table A1.1

North-East region of Brazil: type I production, employment and income multipliers, 2011

\begin{tabular}{|c|c|c|c|c|c|c|c|c|c|c|c|}
\hline \multirow{2}{*}{ Sector } & \multicolumn{3}{|c|}{ Type I multipliers } & \multirow{2}{*}{ Sector } & \multicolumn{3}{|c|}{ Type I multipliers } & \multirow{2}{*}{ Sector } & \multicolumn{3}{|c|}{ Type I multipliers } \\
\hline & Employment & Income & Production & & Employment & Income & Production & & Employment & Income & Production \\
\hline 1 & 1.0610 & 1.2306 & 1.5629 & 38 & 20.1414 & 3.8610 & 1.7934 & 75 & 80.0401 & 10.7379 & 1.9983 \\
\hline 2 & 1.0152 & 1.0814 & 1.3404 & 39 & 10.4201 & 3.6488 & 2.2075 & 76 & 1.9771 & 1.2401 & 1.3247 \\
\hline 3 & 1.3704 & 1.6294 & 1.3347 & 40 & 9.2598 & 3.3028 & 2.2574 & 77 & 1.3147 & 1.2304 & 1.5578 \\
\hline 4 & 1.0153 & 1.1703 & 1.3510 & 41 & 7.4355 & 2.7333 & 2.1801 & 78 & 1.3303 & 1.8623 & 1.7103 \\
\hline 5 & 1.1324 & 1.5127 & 1.4761 & 42 & 6.9810 & 15.4360 & 2.4469 & 79 & 1.3066 & 1.1933 & 1.3123 \\
\hline 6 & 1.1931 & 1.4597 & 1.5795 & 43 & 6.3801 & 5.8975 & 2.3114 & 80 & 1.2635 & 1.1641 & 1.2884 \\
\hline 7 & 1.0890 & 1.1988 & 1.3210 & 44 & 18.9709 & 3.9483 & 2.3227 & 81 & 1.1721 & 1.2354 & 1.3874 \\
\hline 8 & 1.1212 & 1.3583 & 1.6299 & 45 & 2.7822 & 2.3543 & 2.1121 & 82 & 1.1487 & 1.2193 & 1.3661 \\
\hline 9 & 1.0599 & 1.4378 & 1.6757 & 46 & 3.4064 & 1.8521 & 1.8491 & 83 & 1.0673 & 1.1894 & 1.3241 \\
\hline 10 & 1.8175 & 1.8438 & 1.9089 & 47 & 19.7539 & 4.5913 & 2.2584 & 84 & 1.4524 & 1.8784 & 1.7690 \\
\hline 11 & 1.1983 & 1.5198 & 1.7464 & 48 & 4.0184 & 2.0827 & 2.0650 & 85 & 10.7877 & 3.8855 & 2.1615 \\
\hline 12 & 1.0662 & 1.3687 & 1.7676 & 49 & 7.9493 & 2.3100 & 2.3043 & 86 & 1.8228 & 1.4757 & 1.8573 \\
\hline 13 & 38.7929 & 2.6379 & 1.9185 & 50 & 2.9262 & 2.3720 & 2.2372 & 87 & 3.6958 & 2.1877 & 1.8821 \\
\hline 14 & 29.3068 & 3.0267 & 1.9252 & 51 & 5.0258 & 2.1699 & 2.1450 & 88 & 2.5914 & 2.5286 & 2.0960 \\
\hline 15 & 2.4112 & 1.2021 & 1.4728 & 52 & 1.9191 & 1.8454 & 2.2951 & 89 & 1.4143 & 1.3997 & 1.7323 \\
\hline 16 & 8.9887 & 3.6018 & 1.7752 & 53 & 8.8002 & 2.2286 & 1.7931 & 90 & 1.2403 & 1.3733 & 1.7227 \\
\hline 17 & 1.5695 & 1.7090 & 1.8199 & 54 & 2.5234 & 2.0642 & 1.9058 & 91 & 6.6024 & 2.1911 & 2.0959 \\
\hline 18 & 29.7316 & 5.0114 & 2.3005 & 55 & 1.4927 & 1.7492 & 1.9776 & 92 & 1.7023 & 1.2517 & 1.7028 \\
\hline 19 & 13.4425 & 3.8766 & 2.4400 & 56 & 7.2917 & 2.9059 & 2.0366 & 93 & 1.9280 & 1.3035 & 1.6669 \\
\hline 20 & 14.5036 & 4.1864 & 2.3380 & 57 & 2.8568 & 2.7634 & 2.0027 & 94 & 1.3505 & 1.2514 & 1.4950 \\
\hline 21 & 20.3202 & 7.3520 & 2.4728 & 58 & 1.7774 & 1.9088 & 1.9590 & 95 & 1.3098 & 1.1664 & 1.4900 \\
\hline 22 & 7.3290 & 3.8428 & 2.4460 & 59 & 2.7529 & 2.1207 & 2.1604 & 96 & 1.4637 & 2.0419 & 1.6594 \\
\hline 23 & 8.0674 & 3.3269 & 2.2232 & 60 & 1.5288 & 1.7546 & 2.1147 & 97 & 2.3643 & 2.4961 & 1.6577 \\
\hline 24 & 7.4981 & 2.9379 & 2.3467 & 61 & 2.0609 & 2.0218 & 2.1077 & 98 & 1.6343 & 1.4870 & 1.5662 \\
\hline 25 & 12.3703 & 3.1589 & 1.9554 & 62 & 2.3880 & 2.2009 & 2.1491 & 99 & 3.2768 & 1.5778 & 1.5942 \\
\hline 26 & 10.5345 & 3.6901 & 2.4600 & 63 & 6.1804 & 2.5824 & 2.1495 & 100 & 3.9215 & 1.5765 & 1.0689 \\
\hline 27 & 3.9344 & 3.0116 & 2.4205 & 64 & 2.9882 & 1.7897 & 2.0551 & 101 & 1.2768 & 1.1945 & 1.3506 \\
\hline 28 & 6.6452 & 2.5066 & 2.1262 & 65 & 4.6439 & 3.8798 & 2.2872 & 102 & 2.4056 & 1.2308 & 1.6303 \\
\hline 29 & 13.3877 & 2.9401 & 2.1607 & 66 & 1.4977 & 1.6080 & 1.7233 & 103 & 1.3821 & 1.7169 & 1.8674 \\
\hline 30 & 1.8717 & 2.3792 & 2.0568 & 67 & 12.1553 & 3.4727 & 2.5211 & 104 & 1.2100 & 1.3152 & 1.4783 \\
\hline 31 & 1.2523 & 1.7580 & 1.9836 & 68 & 7.2150 & 4.2123 & 2.4808 & 105 & 1.3341 & 1.2027 & 1.5942 \\
\hline 32 & 2.2513 & 2.1879 & 2.3046 & 69 & 3.0403 & 2.1045 & 2.2529 & 106 & 1.4245 & 1.4321 & 1.7428 \\
\hline 33 & 1.8550 & 1.8151 & 1.9619 & 70 & 3.4722 & 2.3190 & 2.2728 & 107 & 1.0770 & 1.1660 & 1.5238 \\
\hline 34 & 28.9656 & 4.5228 & 2.1098 & 71 & 1.8252 & 2.1092 & 1.9711 & 108 & 1.1564 & 1.0619 & 1.2770 \\
\hline 35 & 2.9515 & 1.8823 & 2.0079 & 72 & 1.6153 & 2.1821 & 2.0109 & 109 & 1.7604 & 1.2256 & 1.5724 \\
\hline 36 & 1.7622 & 1.5742 & 1.8362 & 73 & 7.3128 & 1.8755 & 1.2273 & 110 & 1.8203 & 1.2825 & 1.5749 \\
\hline 37 & 98.1900 & 10.8380 & 2.3396 & 74 & 4.8449 & 1.9481 & 1.6135 & 111 & 1.4923 & 1.1939 & 1.4842 \\
\hline
\end{tabular}

Source: Prepared by the authors on the basis of official information.

Note: The sectors are listed in table 3. 


\section{Annex A2}

\section{Type II production, employment and income multipliers in the North-East region, 2011}

Table A2.1

North-East region of Brazil: type II production, employment and income multipliers, 2011

\begin{tabular}{|c|c|c|c|c|c|c|c|c|c|c|c|}
\hline \multirow{2}{*}{ Sector } & \multicolumn{3}{|c|}{ Type II multipliers } & \multirow{2}{*}{ Sector } & \multicolumn{3}{|c|}{ Type II multipliers } & \multirow{2}{*}{ Sector } & \multicolumn{3}{|c|}{ Type II multipliers } \\
\hline & Employment & Income & Production & & Employment & Income & Production & & Employment & Income & Production \\
\hline 1 & 1.1031 & 1.4281 & 1.8964 & 38 & 20.7981 & 4.2940 & 2.0138 & 75 & 96.0721 & 12.0887 & 2.1168 \\
\hline 2 & 1.0380 & 1.2069 & 1.7198 & 39 & 12.9557 & 4.0598 & 2.3331 & 76 & 2.6151 & 1.3628 & 1.4687 \\
\hline 3 & 2.0700 & 2.6087 & 1.6598 & 40 & 11.6067 & 3.6677 & 2.3968 & 77 & 1.5437 & 1.3517 & 1.8023 \\
\hline 4 & 1.0372 & 1.4159 & 1.6968 & 41 & 9.2919 & 3.0377 & 2.3013 & 78 & 1.4981 & 2.1696 & 1.9193 \\
\hline 5 & 1.2197 & 2.0039 & 1.7925 & 42 & 8.3087 & 17.2399 & 2.5509 & 79 & 1.6144 & 1.3684 & 1.5929 \\
\hline 6 & 1.2858 & 1.8181 & 1.8985 & 43 & 7.6214 & 6.5786 & 2.4228 & 80 & 1.5483 & 1.3281 & 1.5782 \\
\hline 7 & 1.1493 & 1.4810 & 1.6802 & 44 & 23.7181 & 4.3913 & 2.4276 & 81 & 1.3091 & 1.4066 & 1.6692 \\
\hline 8 & 1.1884 & 1.6499 & 2.0388 & 45 & 3.3501 & 2.6098 & 2.2356 & 82 & 1.2652 & 1.3857 & 1.6540 \\
\hline 9 & 1.0829 & 1.7474 & 2.0666 & 46 & 4.1063 & 2.0511 & 2.0332 & 83 & 1.1190 & 1.3558 & 1.6105 \\
\hline 10 & 2.0871 & 2.3044 & 2.2885 & 47 & 23.1338 & 5.1088 & 2.3870 & 84 & 1.6580 & 2.2064 & 1.9986 \\
\hline 11 & 1.2572 & 1.8485 & 2.1454 & 48 & 4.7394 & 2.3201 & 2.2419 & 85 & 14.3167 & 4.5096 & 2.3513 \\
\hline 12 & 1.0877 & 1.5989 & 2.1533 & 49 & 9.9259 & 2.5665 & 2.4716 & 86 & 2.2710 & 1.6352 & 2.1122 \\
\hline 13 & 48.0909 & 2.9363 & 2.0709 & 50 & 3.4319 & 2.6365 & 2.3951 & 87 & 4.9078 & 2.5741 & 2.0924 \\
\hline 14 & 35.8448 & 3.3757 & 2.0681 & 51 & 5.9869 & 2.4216 & 2.3004 & 88 & 3.1631 & 2.9275 & 2.3414 \\
\hline 15 & 3.4865 & 1.3211 & 1.7277 & 52 & 2.2801 & 2.0379 & 2.4691 & 89 & 1.6870 & 1.5853 & 1.9922 \\
\hline 16 & 10.7869 & 4.0221 & 1.8721 & 53 & 11.1774 & 2.4754 & 1.9165 & 90 & 1.3962 & 1.5533 & 1.9823 \\
\hline 17 & 1.7934 & 1.9048 & 1.9892 & 54 & 3.0424 & 2.3055 & 2.0688 & 91 & 8.9529 & 2.4878 & 2.3055 \\
\hline 18 & 32.0626 & 5.8864 & 2.5955 & 55 & 1.6735 & 1.9417 & 2.1633 & 92 & 2.3063 & 1.3778 & 2.0225 \\
\hline 19 & 14.8433 & 4.5699 & 2.7225 & 56 & 9.1601 & 3.2282 & 2.1518 & 93 & 2.6736 & 1.4745 & 1.9247 \\
\hline 20 & 15.4027 & 4.9165 & 2.6401 & 57 & 3.4338 & 3.0664 & 2.1190 & 94 & 1.6547 & 1.4224 & 1.7842 \\
\hline 21 & 25.1616 & 9.2273 & 2.7217 & 58 & 2.1457 & 2.1389 & 2.1160 & 95 & 1.5923 & 1.2845 & 1.7606 \\
\hline 22 & 7.9000 & 4.4391 & 2.7384 & 59 & 3.4318 & 2.3473 & 2.3305 & 96 & 1.5941 & 2.3183 & 1.8260 \\
\hline 23 & 8.5199 & 3.8530 & 2.4861 & 60 & 1.7645 & 1.9375 & 2.3115 & 97 & 2.7690 & 2.8616 & 1.8098 \\
\hline 24 & 8.3630 & 3.4324 & 2.5930 & 61 & 2.4770 & 2.2389 & 2.2771 & 98 & 1.9188 & 1.6591 & 1.7876 \\
\hline 25 & 12.8413 & 3.5054 & 2.1962 & 62 & 2.8603 & 2.4351 & 2.3177 & 99 & 4.2172 & 1.7431 & 1.7812 \\
\hline 26 & 11.6323 & 4.3496 & 2.7230 & 63 & 7.8418 & 2.8664 & 2.3170 & 100 & 5.0929 & 1.8217 & 1.0949 \\
\hline 27 & 4.3260 & 3.4869 & 2.6616 & 64 & 3.8362 & 1.9764 & 2.2404 & 101 & 1.8652 & 1.4305 & 1.7033 \\
\hline 28 & 7.3866 & 2.8288 & 2.3561 & 65 & 5.5107 & 4.3179 & 2.4430 & 102 & 3.1556 & 1.3716 & 1.9602 \\
\hline 29 & 14.8288 & 3.4461 & 2.3885 & 66 & 1.7524 & 1.7939 & 1.9051 & 103 & 1.4869 & 1.9871 & 2.1509 \\
\hline 30 & 2.0364 & 2.7289 & 2.2506 & 67 & 15.3430 & 3.8560 & 2.7148 & 104 & 1.3612 & 1.4971 & 1.7556 \\
\hline 31 & 1.3295 & 2.0627 & 2.2846 & 68 & 8.8601 & 4.6785 & 2.6583 & 105 & 1.5472 & 1.3285 & 1.9444 \\
\hline 32 & 2.5449 & 2.4451 & 2.5416 & 69 & 3.7748 & 2.3253 & 2.4425 & 106 & 1.6282 & 1.6146 & 2.0546 \\
\hline 33 & 2.0143 & 2.0349 & 2.1885 & 70 & 4.2979 & 2.5663 & 2.4561 & 107 & 1.1352 & 1.2927 & 1.8951 \\
\hline 34 & 32.1407 & 5.2212 & 2.2836 & 71 & 2.0814 & 2.4000 & 2.1692 & 108 & 1.4260 & 1.1630 & 1.6985 \\
\hline 35 & 3.5056 & 2.0891 & 2.1832 & 72 & 1.8450 & 2.4882 & 2.1976 & 109 & 2.1977 & 1.3474 & 1.9118 \\
\hline 36 & 2.1069 & 1.7476 & 2.0505 & 73 & 8.9747 & 2.0736 & 1.2748 & 110 & 2.3155 & 1.4096 & 1.8322 \\
\hline 37 & 118.5966 & 12.0601 & 2.4499 & 74 & 6.2108 & 2.1490 & 1.6845 & 111 & 1.8822 & 1.3104 & 1.7816 \\
\hline
\end{tabular}

Source: Prepared by the authors on the basis of official information.

Note: The sectors are listed in table 3. 